\title{
IAMJ
}

INTERNATIONAL

AYURVEDIC

MEDICAL JOURNAL

\section{EXPERIMENTAL STUDY ON Ellertonia rheedii Wight. LEAF FOR ITS DERMAL TOXICITY}

\section{Arundeep. M}

Assistant Professor, Dept. Dravyaguna Vijnana, Yenepoya Ayurveda Medical College and Hospital, Naringana, Deralakatte, Mangaluru, Karnataka, India

Corresponding Author: m.arundeep@gmail.com

\section{https://doi.org/10.46607/iamj.2809012021}

(Published online: January 2021)

Open Access

(C) International Ayurvedic Medical Journal, India 2021

Article Received:19/12/2020 - Peer Reviewed:22/12/2020 - Accepted for Publication:25/12/2020

Check for updates

\begin{abstract}
Ellertonia rheedii Wight is an indigenous plant belonging to Apocynaceae family found in Western Ghats of Coorg, Shimoga, Chikamagalore, Dakshina Kannada. The paste of fresh leaves of this plant is used externally in varicose vein by folklore practitioner in and around Dakshina Kannada District of Karnataka State. In local language it is called "Nara balli" which means a climber used for the disease of vein. The name itself indicates its long-term use among the folk and efficacy of the drug. The identity of Ellertonia rheedii Wight is yet explored in Ayurvedic literature. Current study was carried out to evaluate the dermal toxicity activity of leaves of Ellertonia rheedii Wight.
\end{abstract}

Keywords: Apocynaceae, Ellertonia rheedii Wight, Folklore

\section{INTRODUCTION}

The conventional Indian medication has another stream called "folklore medicine" managing with single drugs or compound from the immediately available resource for the management of conditions like pain, oedema, pyrexia, diarrhea, diarrhea, etc. The folk medicine or tribal medicine has given wealthy commitment to the advancement of Materia medica of Ayurveda. Ellertonia rheedii Wight was an indigenous plant belonging to Apocynaceae family, found in Western Ghats, from South Karnataka to Travancore, 
up to an altitude of $3000 \mathrm{ft}^{1}$. "Nara balli" which means a woody climber used for the disease of vein in and around Edapadavu, Mijar ofMoodbidri². Botanical synonyms ${ }^{3}$ of this Plant is Ellertoniarheedii Wight, Echitescaryophyllatais a synonym of Kamettiacaryophyllata (Roxb.) Nicolson \& Suresh in 1848.Vernacular names ${ }^{4}$ Kannada- Naraballi, Narasoodiballi., Malayalam-Naramarathiru. Taxonomical classification

Kingdom- Plantae, Sub kingdom-Tracheophyta, Super division- Spermatophyta- Seed plants, DivisionMagnoliophyta- Flowering plants, Class- Magnoliopsida-Dicotyledons, Order- Gentianales, FamilyApocynaceae, Genus- Ellertonia, Species - Rheedii Wight.

Distribution and Habitat: Western ghats, evergreen forest from Travancore and Tinnevelly, up to $3000 \mathrm{ft}$. This species are rare and apparently endemic to Western Ghats.

Objective of the study: Experimental study on Ellertoniarheedii Wight. leaf by Acute dermal toxicity.

Materials and methods

Acute dermal toxicity study has been done on the basis of OECD 402 guidelines for the testing of chemicals. In the assessment and evaluation of the toxic characteristics of a substance, determination of acute dermal toxicity is useful where exposure by the dermal route is likely. It provides information on health hazards likely to arise from a short-term exposure by the dermal route. Data from an acute dermal toxicity study may serve as a basis for classification and labelling. It is an initial step in establishing a dosage regimen in sub chronic and other studies and may provide information on dermal absorption and the mode of toxic action of a substance by this route.

1. Definition-Acute dermal toxicity is the adverse effects occurring within a short time of dermal application of a single dose of a test substance.

2. Dose-Dose is the amount of test substance applied. Dose is expressed as weight ( $\mathrm{g}, \mathrm{mg}$ ) or as weight of test substance per unit weight of test animal (e.g. $\mathrm{mg} / \mathrm{kg}$ ).

3. Preparation: Healthy young 6 adult animals was acclimatised to the laboratory conditions for at least5 days prior to the test. Approximately24 hours before the test, fur is removed from the dorsal area of the trunk of the test animals by clipping or shaving. Care was taken to avoid abrading the skin, which could alter its permeability. Not less than 10 percent of the body surface area was cleared for the application of the test substance. The weight of the animal was taken into account when deciding on the area to be cleared and on the dimensions of the covering.

\section{Selection of animals}

a. Wistar strain albino rats was selected from animal house of Alva's Ayurveda Research Centre, Moodbidri

b. Rats was maintained under strict laboratory condition, controlled with environmental, temperature, humidity and light dark cycle.

c. Rats was fed with balanced pelleted diet commercially obtained from Amritha feeds.30gm/day and mineral water of volume $300 \mathrm{ml} /$ day is given.

\section{Inclusion criteria}

a. Not less than 8-week-old adult albino rats of both the sex.

b. Weight about 150-200gm will select in random.

\section{Exclusion criteria}

a. Diseased rat

b. Rats bellow 150 gms and more than 200 gms.

7. Observation period: The observation period should be atleast 14days. However, the duration of observation should not be fixed rigidly. It should be determined by the toxic reactions, rate of onset and length of recovery period, and may thus be extended when considered necessary. The time at which signs of toxicity appear and disappear, their duration and the time of death are important, especially if there is a tendency for deaths to be delayed.

Result: Five animals survived without showing any signs of toxicity. And there were no signs of derma toxicity like oedema, erythema, when they were observed for the next 14 days. (Table.1,figure 1,2)

\section{DISCUSSION}

Ellertonia rheedii Wight.is an indigenous plant belonging to Apocynaceae family, found in Western 
ghats, from South Karnataka to Travancore, up to an altitude of $3000 \mathrm{ft}$. The identity of Ellertoniarheedii Wight.t. is not yet explored in Ayurvedic literature. In local Kannada language it is called "Nara balli" which means a woody climber used for the disease of vein in and around Edapadavu, Mijar of Moodbidri. Locally leaves of this species are used in making salad and as spice. 1814 Roxberg the identity published as $\mathrm{Ka}$ mettia caryophyllata. Ellertonia rheedii Wight. and Echitescaryophyllata are the synonyms accepted in 1848.As the five animals survived without showing any signs of toxicity, and there were no signs of derma toxicity like oedema, erythema, when they were observed for the next 14 days.

\section{CONCLUSION}

Ellertonia rheedii Wight is a drug well known for its folklore importance and have been noticed widely for its traditional usage. Hence it deserves an important place in bio-diversity. The Preliminary phytochemical study of Ellertonia rheedii Wight leaves shows the presence of Proteins, Steroids, Tannins, Phenolics. The Pharmacological study reveals that the leaf of the plant Ellertonia rheedii wight having Kashaya, tikta as Pradhana rasa and Madhura as Anurasa. Ash analysis showed the presence of Ash analysis of Ellertonia rheedii wight showed the presence of Fluorides, Chlorides, Sulphates, Phosphates. Acute dermal toxicity study of Leaf Kalka of Ellertonia rheedii Wight reveals that they do not cause any toxic symptoms.

\section{REFERENCES}

1. J.S. Gamble, Flora of the Presidency of Madras, Published under the authority of the secretary of the State for India in Council, 2006, Pg no 810.

2. Dr. Subhrahmanya. P, Ethino-Medico-Botany of Kalanjimale Range and Clinical evaluation of Nondocumented Medicinal Plants in Prevalent skin Diseases, $\mathrm{PhD}$ thesis, 2011.

3. The plant list.org, http://ipni.org/urn:1sid:ipni.org:names:78853-1.

4. Dr. Arundeep. M, Pharmacognostic and phytochemical essay of Ellertoniarheedii Wight, International Ayurvedic Medical Journal, India 2019Published online: September, 2019

5. J.S. Gamble, Flora of the Presidency of Madras, Published under the authority of the secretary of the State for India in Council, 2006, Pg no 810.

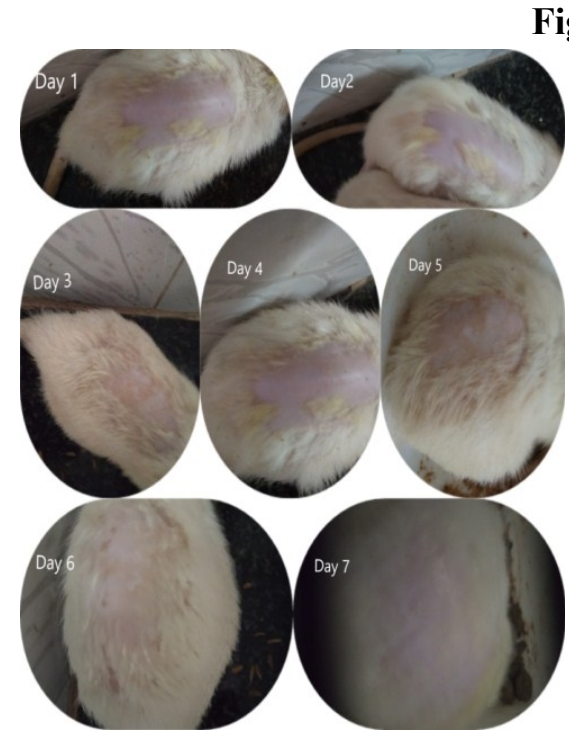

Figure 1

Figure

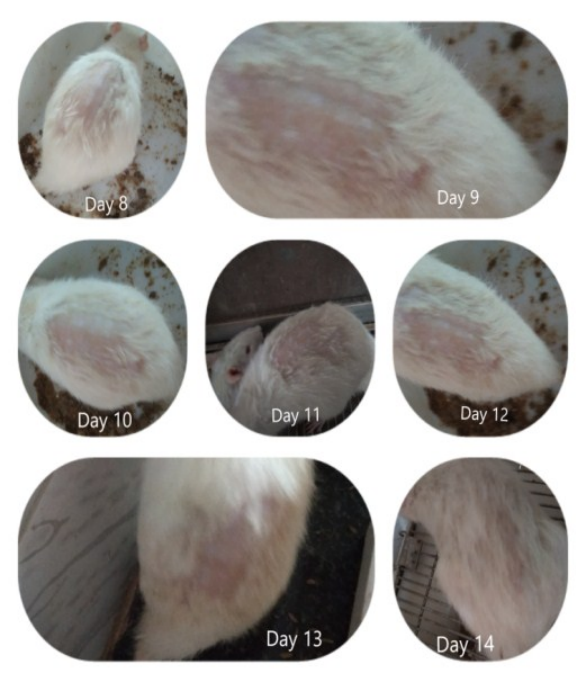

Figure 2 
Table 1: Acute dermal toxicity

\begin{tabular}{|c|c|c|c|c|c|c|c|}
\hline Observation & Day1 & Day2 & Day3 & Day4 & Day5 & Day6 & Day7 \\
\hline Local signs & No signs & No signs & No signs & No signs & No signs & No signs & No signs \\
\hline Observation & Day8 & Day9 & Day10 & Day11 & Day12 & Day13 & Day14 \\
\hline Local signs & No signs & No signs & No signs & No signs & No signs & No signs & No signs \\
\hline
\end{tabular}

\section{Source of Support: Nil}

\section{Conflict of Interest: None Declared}

How to cite this URL: Arundeep. M et al: Experimental Study On Ellertonia Rheedii Wight. Leaf for Its Dermal Toxicity. International Ayurvedic Medical Journal \{online\} 2021 \{cited January, 2021\} Available from: http://www.iamj.in/posts/images/upload/175_178.pdf 